\title{
FORMULA BERBAHAN AKTIF PSEUDOMONAD FLUORESEN DAN PENGARUHNYA TERHADAP PERKEMBANGAN PENYAKIT LAYU PADA CABAI
}

\author{
Yenny Wuryandari, Sri Wiyatiningsih, \& Maroeto \\ Fakultas Pertanian UPN "Veteran" Jawa Timur \\ Jl. Raya Rungkut Madya, Surabaya, Jawa Timur \\ E-mail: yennyupn@yahoo.com
}

\begin{abstract}
Formula with active ingridient of fluorescent pseudomonads and its influence on wilt disease development of pepper. The purpose of this study was to synergize organic fertilizer with biopesticides of fluorescent pseudomonads 122 to be the best formula to increase the resistance of pepper plants to wilt disease. The study used a completely randomized design (CRD), which consisted of four treatments. The treatments were forms of active ingredient formula of fluorescent pseudomonads (powder, pellet, granule, and liquid). The effectiveness of the formula in suppressing development of the disease was measured by observing the incubation period, index of the disease and discoloration of vascular tissue of pepper. The results showed that the disease incubation period of plant treated with liquid and powder formula was longer than formula with granule and pellet. Plants treated with powder formula showed the lowest disease index compared to control, liquid, pellet and granule formula. Disease index and discoloration in vascular tissue was also of the lowest value when the plants were treated with powder formula. This result indicate that active ingredient of fluorescent pseudomonads formulated in powder was the most effective to inhibit the development of wilt disease on pepper caused by Fusarium sp. and Ralstonia solanacearum.
\end{abstract}

Key words: fluorescent pseudomonads, pepper, wilt disease

\begin{abstract}
ABSTRAK
Formula berbahan aktif pseudomonad fluoresen dan pengaruhnya terhadap perkembangan penyakit layu pada cabai. Tujuan penelitian ini untuk mensinergikan pupuk organik dengan biopestisida pseudomonad fluoresen 122 menjadi formula terbaik untuk meningkatkan ketahanan tanaman cabai terhadap penyakit layu. Penelitian menggunakan rancangan acak lengkap (RAL) yang terdiri dari empat perlakuan. Keempat perlakuan tersebut adalah bentuk formula dengan bahan aktif pseudomonad fluoresen yaitu formula serbuk, pelet, granul, dan cair. Keefektifan formula dalam menekan perkembangan penyakit, diukur dengan mengamati masa inkubasi, indeks penyakit dan perubahan warna jaringan pembuluh pada tanaman cabai. Hasil penelitian menunjukkan bahwa pada pengamatan masa inkubasi yang diperlakukan dengan formula cair dan serbuk terlihat lebih lama dibandingkan formula granul dan pelet. Adapun hasil pengamatan terhadap indeks penyakit yang diperlakukan dengan formula serbuk menunjukkan hasil yang paling rendah dibandingkan dengan kontrol, cair, pelet dan granul. Sampai akhir pengamatan indeks penyakit dan panjang perubahan warna pada jaringan pembuluh, dengan pemberian formula serbuk menunjukkan nilai paling rendah. Keadaan tersebut menunjukkan bahwa perlakuan dengan pemberian formula berbahan aktif serbuk paling mampu menghambat perkembangan penyakit layu pada cabai yang disebabkan oleh Fusarium sp. dan Ralstonia solanacearum.
\end{abstract}

Kata kunci: cabai, penyakit layu, pseudomonad fluorescen

\section{PENDAHULUAN}

Cabai mempunyai prospek permintaan yang baik, tetapi sektor budidayanya masih menghadapi berbagai kendala (Anonim, 2009). Salah satu kendala yang sangat mempengaruhi produksi cabai adalah penyakit utama yaitu penyakit yang disebabkan oleh Ralstonia solanacearum dan Fusarium oxysporum. Kerugian akibat penyakit ini semakin tinggi karena sering kali keduanya secara bersama menyerang tanaman cabai.
Sampai saat ini upaya pengendalian penyakit layu pada cabai belum teratasi. Salah satu pengendalian yang ramah lingkungan, dan merupakan komponen yang sangat penting dalam pengendalian secara terpadu, adalah pengendalian biologi. Pada penelitian sebelumnya, telah didapatkan rhizobakteria pseudomonad fluoresen terbaik yang mampu menghambat penyakit layu cabai yang disebabkan oleh $F$. oxysporum dan $R$. solanacearum. Rhizobakteria pseudomonad fluoresen juga mampu memacu pertumbuhan serta meningkatkan 
produksi cabai (Wuryandari et al., 2012). Aplikasi pengujian adalah dengan cara pencelupan akar. Cara pencelupan akar masih ada kelemahannya atau belum optimum karena tidak praktis dalam skala lapang, sehingga masih harus dikembangkan dengan pembuatan formula yang tepat untuk pengendalian penyakit layu dan sekaligus untuk meningkatkan produksi tanaman cabai.

Pengendalian biologi menggunakan mikroorganisme antagonis yang telah diformulasikan diharapkan dapat mengendalikan penyakit tersebut secara efektif dan efisien. Sebelumnya telah dilakukan penelitian pembuatan formula dengan bahan aktif rhizobakteria pseudomonad fluoresen tetapi hanya untuk pengendalian penyakit layu bakteri $R$. solanacearum saja. Formulasi yang telah diuji tersebut di atas dalam bentuk pil-benih dan pelet dengan bahan pembawa pupuk kandang yang dijual bebas di pasaran dan bukan produksi dari Pabrik Mini Pupuk Organik UPN "Veteran" Jawa Timur. Hasil yang diperoleh belum menunjukkan hasil yang optimal, di samping cara pembuatan formula pilbenih cukup sulit dan viabilitasnya masih rendah (Wuryandari et al., 2011).

Beberapa produk usaha Unit Produksi pupuk organik yang dihasilkan oleh Pabrik Mini Pupuk Organik di UPN "Veteran" Jawa Timur antara lain pupuk kompos dari limbah tanaman (serbuk), pupuk organik kombinasi kompos dan kotoran sapi (pelet), pupuk organomineral (granul) dan pupuk cair (cair). Produkproduk yang dihasilkan tersebut adalah pupuk yang berasal dari bahan organik berfungsi menambah nutrisi dalam tanah. Hasil penelitian Augustien et al. (2012), menunjukkan bahwa pemberian pupuk organik bentuk granul, dan serbuk yang dihasilkan oleh Pabrik Mini Pupuk Organik di UPN "Veteran" Jawa Timur dapat meningkatkan pertumbuhan dan produksi tanaman cabai dibandingkan kontrol. Produksi dan pemasaran pupuk organik di Pabrik Mini Pupuk Organik di UPN "Veteran" Jawa Timur masih belum maksimal. Produksi pupuk organik cair sebanyak 250-500 1/bulan, pupuk serbuk 2-3 ton/bulan dan yang berbentuk granul sebanyak 500 $\mathrm{kg}-1$ ton/bulan. Untuk pengembangan dan peningkatan produk pupuk organik, masih sangat diperlukan penyempurnaan formula dengan mengkombinasi pupuk organik dari Pabrik Mini Pupuk Organik di UPN "Veteran" Jawa Timur dengan biopestisida pseudomonad fluoresen 122. Dari penelitian ini diharapkan diperoleh satu formula yang terbaik untuk meningkatkan ketahanan tanaman cabai terhadap penyakit layu.

\section{METODE PENELITIAN}

Tempat dan Waktu. Penelitian dilaksanakan di Laboratorium Kesehatan Tanaman dan di Pabrik Mini Pupuk Organik di UPN "Veteran" Jawa Timur, serta di rumah kaca Fakultas Pertanian, UPN "Veteran" Jawa Timur, pada bulan Juni 2014.

Rancangan Penelitian. Penelitian ini menggunakan Rancangan Acak Lengkap (RAL) yang terdiri dari 4 perlakuan. Perlakuan tersebut adalah bentuk formula dengan bahan aktif bakteri pseudomonad fluoresen 122 yaitu formula serbuk, granul, pelet, dan cair. Formula dibuat dengan mengkombinasikan bahan pembawa berupa pupuk organik produk Pabrik Mini UPN Jatim serta inokulum rhizobakteria pseudomonad fluorescens. Bahan pembawa formulasi yang digunakan antara lain blotong $3 \mathrm{~kg}$, kotoran sapi $1 \mathrm{~kg}$, kandarwati $3 / 4 \mathrm{~kg}$, dan guano $1 / 2 \mathrm{~kg}$. Semua bahan selanjutnya dicampur dengan rhizobakteria pseudomonad fluoresen dengan konsentrasi $10^{10} \mathrm{CFU} / \mathrm{ml}$, dimasukkan pada alat pembuat pupuk sehingga campuran yang terbentuk berupa beberapa formula yaitu serbuk, granul, pelet dan cair. Pengujian terhadap bibit tanaman cabai sebelum dipindah ke polibag, media tanam diberi formula sebanyak $10 \mathrm{~g}$ pada lubang tanamnya dan sebelumnya telah diberi suspensi patogen $R$. solanacearum dan $F$. oxysporum dengan dosis masing-masing $10 \mathrm{ml}$ per lubang tanam. Adapun konsentrasi untuk $R$. solanacearum adalah $10^{8}$ CFU/ml dan Fusarium sp. konsentrasi $10^{7}$ spora/ml. Keefektifan formula dalam menekan perkembangan penyakit, dengan mengamati masa inkubasi dan indeks penyakit, dan perubahan warna pada jaringan pembuluh pada tanaman cabai. Masing-masing perlakuan diulang 3 kali.

\section{Pengamatan Masa Inkubasi dan Indeks Penyakit.} Parameter pengamatan penelitian meliputi a). Masa inkubasi, diamati mulai dari inokulasi patogen sampai munculnya gejala layu pada tanaman cabai. Masa inkubasi diamati setiap hari, b). Indeks penyakit diamati perkembangan gejala layu setiap 5 hari sampai hari ke30 setelah inokulasi. Berat serangan dihitung menurut skala sebagai berikut:

$0=$ tidak ada gejala

$1=1-10 \%$ daun layu

$2=11-30 \%$ daun layu

$3=31-60 \%$ daun layu

$4=61-99 \%$ daun layu

$5=100 \%$ daun layu 
Besarnya indeks penyakit dihitung dengan rumus (Arwiyanto, 1995):

$$
I=\frac{\sum_{i=0}^{k} k \cdot n k}{Z x N} \times 100 \%
$$

dengan :

$$
\begin{aligned}
\mathrm{I} & =\text { indeks penyakit } \\
\mathrm{k} & =\text { skala atau skor } \\
\mathrm{nk} & =\text { jumlah tanaman yang bergejala sakit dengan } \\
& \text { skala } \mathrm{k}(0,1,2,3,4,5) \\
\mathrm{N} & =\text { jumlah total tanaman yang diinokulasi } \\
\mathrm{Z} & =\text { kategori serangan tertinggi }
\end{aligned}
$$

Pengamatan perubahan warna pada jaringan pembuluh dilakukan pada akhir pengamatan dengan cara destruktif yaitu tanaman dicabut dan dibelah batangnya secara pembujur selanjutnya diukur panjang perubahan warna jaringan. Semua uji disusun dalam Rancangan Acak Lengkap dengan tiga ulangan dan data yang diperoleh dianalisis dengan analisis varian (ANOVA).

\section{HASIL DAN PEMBAHASAN}

Waktu Inkubasi. Jika ditinjau dari hasil pengamatan terhadap masa inkubasi, keempat formula yaitu formula serbuk, granul, pelet dan cair menunjukkan hasil yang berbeda (Tabel 1). Masa inkubasi (munculnya gejala layu) paling cepat terdapat pada perlakuan formula pelet dan granul. Adapun pada formula serbuk dan formula cair masa inkubasi lebih lama yaitu 11 dan 13 hari. Apabila dibandingkan dari keempat formula maka pemberian formula serbuk dan formula cair mampu menunda munculnya gejala penyakit layu kurang lebih 2 sampai 4 hari. Hal tersebut mungkin bahan aktif bakteri pseudomonad fluoresen 122 pada formula berupa serbuk dan cair, lebih mudah berkembang dalam tanah pada awal aplikasi, sehingga populasi awal bakteri pseudomonad fluoresen 122 mampu menahan infeksi patogen penyebab layu dibandingkan formula pelet dan granul yang masih harus memerlukan waktu lebih lama untuk berkembang dalam tanah.

Hasil penelitian sebelumnya menunjukkan bahwa bakteri mampu memacu ketahanan sistemik tanaman dengan memproduksi fitohormon, melarutkan fosfat anorganik, meningkatkan pengikatan $\mathrm{Fe}$ dengan siderofor (Podile \& Kishore, 2007; Haas \& Defago, 2005). Bakteri genus Pseudomonas juga memproduksi senyawa antimikroba atau senyawa penghambat yang berperan sebagai agens hayati seperti phenazine, pyrrolnitrin, pyluteorin, phloroglucinols, cyclic lipopeptides, dan hydrogen cyanida (Haas \& Defago, 2005).

Indeks penyakit. Perkembangan penyakit mulai inokulasi sampai pengamatan hari ke-35 setelah inokulasi dapat dilihat pada Gambar 1. Pengamatan terakhir perlakuan dengan formula serbuk menunjukkan indeks penyakit paling rendah yaitu $41,67 \%$ kemudian diikuti granul dan pelet yaitu 49,17\% dan 52,5\% (Tabel 2).

Dari keempat formula yang diuji, nampak bahwa formula serbuk paling efektif dalam menekan perkembangan penyakit layu (indeks penyakit $=41,67$ $\%)$. Keadaan tersebut mungkin karena dalam formula serbuk bakteri pseudomonad fluoresen 122 lebih dapat berkembang karena kondisi tidak padat seperti formula pelet dan granul, sehingga kebutuhan oksigen tercukupi dan populasi bakteri lebih tinggi. Menurut Palleroni (1984), bakteri Pseudomonas fluorescens termasuk bakteri obligat aerob.

Populasi bakteri pseudomonad fluoresen yang tinggi pada daerah perakaran akan lebih dapat menekan populasi patogen penyebab penyakit layu. Adapun formula cair, walaupun pada awal bakteri mampu menunda masa inkubasi, tetapi kurang dapat menekan perkembangan penyakit layu. Hal tersebut mungkin karena bakteri pseudomonad fluoresecens dalam formula cair tidak mampu berkembang dengan baik. Hal ini mungkin karena terjadinya proses fermentasi pada bahan-bahan yang ada pada pupuk cair yang menghambat pertumbuhan bakteri. Selain itu mungkin

Tabel 1. Masa inkubasi penyakit layu pada cabai di rumah kaca yang diperlakukan dengan formula berbahan aktif pseudomonad fluoresen

\begin{tabular}{cc}
\hline Formula & Rata-rata masa inkubasi (hari) \\
\hline Serbuk & $11 \mathrm{~b}$ \\
Granul & $10 \mathrm{ab}$ \\
Pelet & $9 \mathrm{a}$ \\
Cair & $13 \mathrm{c}$ \\
\hline
\end{tabular}

Angka yang diikuti huruf yang sama dalam satu kolom menunjukkan nilai tidak berbeda nyata berdasarkan uji BNT pada taraf $5 \%$. 


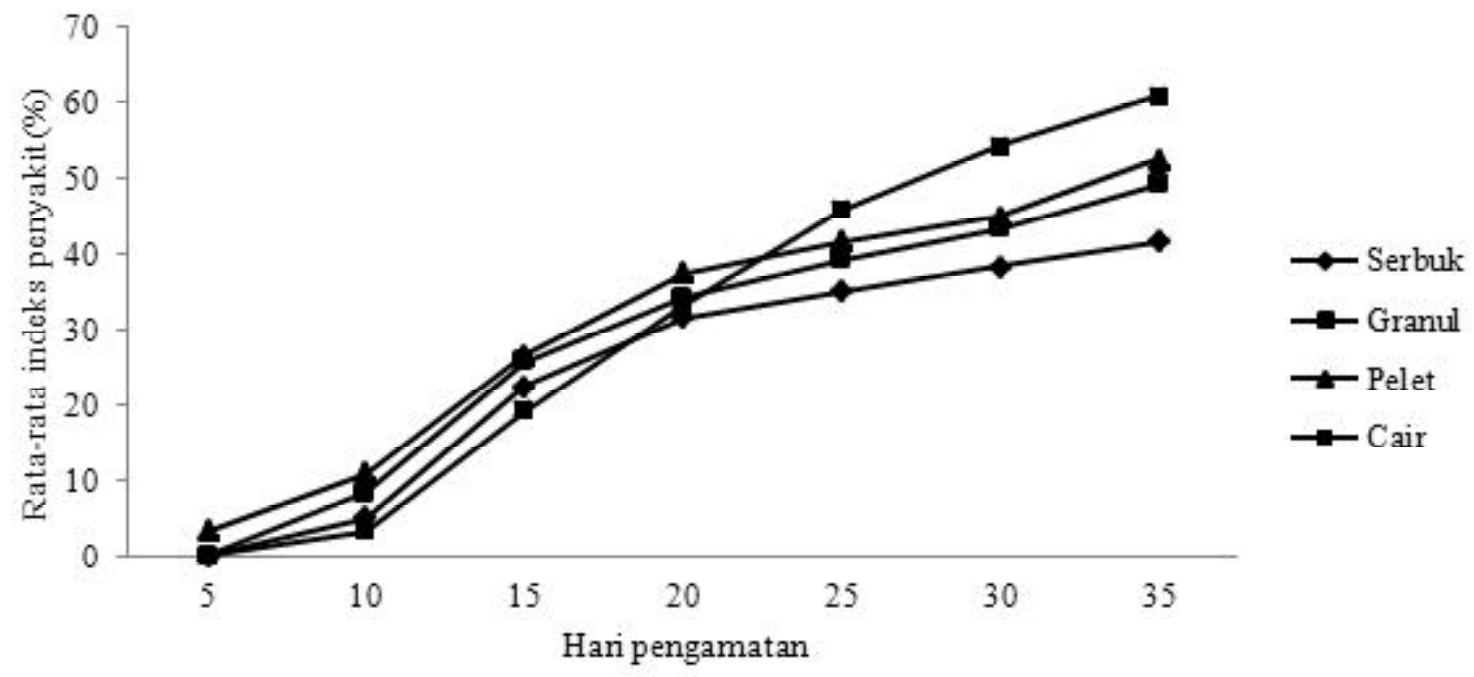

Gambar 2. Perkembangan penyakit layu pada cabai setelah diperlakukan dengan formula berbahan aktif Pseudomonad fluorescens 122

Tabel 2. Indeks penyakit layu pada tanaman cabai dengan perlakuan formula berbahan aktif pseudomonad fluoresen

\begin{tabular}{cc}
\hline Formula & Indeks Penyakit (\%) hari ke-35 \\
\hline Serbuk & $41,67 \mathrm{a}$ \\
Granul & $49,17 \mathrm{bc}$ \\
Pelet & $52,50 \mathrm{c}$ \\
Cair & $60,83 \mathrm{~d}$ \\
\hline
\end{tabular}

Angka yang diikuti huruf yang sama dalam satu kolom menunjukkan nilai tidak berbeda nyata berdasarkan uji BNT pada taraf $5 \%$.

bakteri dalam media cair yang kondisinya kurang oksigen juga dapat menghambat pertumbuhan bakteri pseudomonad fluoresecens 122 . Kondisi $\mathrm{pH}$ dari formula cair yang cukup tinggi yaitu 8,6 nampaknya juga kurang sesuai bagi bakteri pseudomonad fluoresen 122 sehingga dapat menurunkan populasinya. Seperti hasil penelitian Lebert et al. (1998), kisaran $\mathrm{pH}$ untuk pertumbuhan bakteri Pseudomonas fluorescens adalah $\mathrm{pH}$ 5,8 - 7,0. Populasi bakteri pseudomonad fluoresen yang rendah dalam sistem perakaran pada formula cair menyebabkan kurang dapat menghambat perkembangan penyakit layu.

Mekanisme pengendalian hayati patogen tanaman oleh rhizobakteria dapat berupa produksi metabolit bakteri. Rhizobakteria juga mampu memacu pertumbuhan tanaman dengan memproduksi zat pengatur tumbuh seperti turunan auxin (Pinton et al., 2001). Sebagian besar rhizobakteria seperti Pseudomonas, Bacillus, Azotobacter memproduksi senyawa pemacu pertumbuhan seperti Indolacetic acid
(IAA), gibberellin, dan substansi lain seperti cytokinin (Brimecombe et al., 2001). Bakteri genus Pseudomonas juga memproduksi senyawa antimikroba atau senyawa penghambat seperti phenazine, pyrrolnitrin, pyluteorin, phloroglucinols, cyclic lipopeptides, dan hydrogen cyanida (Haas \& Defago, 2005).

Perubahan Warna Jaringan Pembuluh. Salah satu gejala penyakit layu adalah adanya perubahan warna pada jaringan pembuluh tanaman. Perubahan warna coklat mulai dari akar, pangkal batang dan naik ke atas sepanjang jaringan pembuluh. Perubahan warna pada jaringan pembuluh, merupakan salah satu indikasi terjadinya degradasi atau kerusakan jaringan pembuluh oleh patogen penyebab penyakit layu. Semangun (1991), mengatakan bahwa gejala dalam antara lain berupa perubahan warna di jaringan pembuluh, tilosis, dan degradasi selulosa di dalam dinding sel. Hasil pengamatan terhadap panjang perubahan warna pada jaringan pembuluh dapat dilihat pada Tabel 3. 
Tabel 3. Rata-rata panjang perubahan warna jaringan pembuluh pada tanaman cabai

\begin{tabular}{cc}
\hline Formula & Panjang Perubahan warna jaringan $(\mathrm{cm})$ \\
\hline Serbuk & $0,67 \mathrm{a}$ \\
Granul & $1,07 \mathrm{~b}$ \\
Pelet & $1,02 \mathrm{~b}$ \\
Cair & $1,16 \mathrm{~b}$ \\
\hline
\end{tabular}

Angka yang diikuti huruf yang sama dalam satu kolom menunjukkan nilai tidak berbeda nyata berdasarkan uji BNT pada taraf $5 \%$.

Perlakuan dengan formula serbuk menunjukkan adanya perubahan warna jaringan yang paling pendek dibandingkan dengan formula yang lain. Hal ini berbanding lurus dengan kemampuan perlakuan formula serbuk dalam menghambat perkembangan penyakit layu. Semakin besar tekanan atau hambatan perkembangan bakteri patogen oleh bakteri antagonis pseudomonad fluoresen dalam formula, semakin kecil kerusakan dalam jaringan pembuluh yang ditandai dengan semakin pendeknya perubahan warna pada jaringan pembuluh.

\section{SIMPULAN}

Aplikasi pseudomonad fluoresen dengan formula serbuk paling efektif dalam menghambat penyakit layu pada cabai ditunjukkan dengan penundaan kemunculan gejala dan menurunkan indeks penyakit serta panjang warna jaringan pembuluh paling rendah dibandingkan dengan formula yang lain.

\section{SANWACANA}

Penelitian ini dapat terlaksana atas biaya Hibah Penelitian Unggulan Perguruan Tinggi Nasional No. 32/ SP2H/P/K7/KM/2014, untuk itu kami ucapkan terima kasih kepada Direktur Penelitian dan Pengabdian kepada Masyarakat, Direktorat Jenderal Pendidikan Tinggi, Kementerian Pendidikan dan Kebudayaan Republik Indonesia.

\section{DAFTAR PUSTAKA}

Anonim. 2009. Budidaya Cabai Merah Keriting di Lahan Kering. http:// www.mojokertokota.go.id. Diunduh 12 Maret 2014.

Arwiyanto T. 1995. Strategi pengendalian penyakit layu bakteri tembakau cerutu di Sumatera Utara secara terpadu. Ekspose Hasil Penelitian Tembakau Deli IV, Medan.

Suhardjono H, Maroeto, Augustien NK, Mindari W, \& . 2012. Studi beda bentuk dan komposisi pupuk organik pada entisol untuk tanaman cabe. Plumula 1(2): 194-201.

Brimecombe MJ, De Lelj FA, \& Lynch JM. 2001. The rhizosphere. The effect of root exudates on rhizosphere microbial populations. In: Pinton R, Varanini Z, \& Nanipieri P (Eds.). The Rhizophere. Biochemistry and Organic Substances at the Soil-Plant Interface. pp. 95-140. Marcel Dekker, Inc. New York-Basel.

Haas D \& Défago G. 2005. Biological control of soil borne pathogens by fluorescent pseudomonads. Nat. Rev. Microbiol. 3(4): 307-319.

Lebert I, Begot C, \& Lebert A. 1998. Growth of Pseudomonas fluorescens and Pseudomonas fragi in a meat medium as affected by $\mathrm{pH}(5.8-$ 7.0) water activity $(0.97-1.00)$ and temperature (7-25 degree C). Int. J. Food Microbiol. 39(12): 53-60.

Palleroni NJ. 1984. Pseudomonadaceae. In: Krieg NR \& Holt JG (Eds.). Bergey's Manual of Systematic Bacteriology. pp. 141-199. The Williams and Wilkins Co. Baltimore.

Pinton R, Varanini Z, \& Nanipieri P. 2001. The Rhizophere as a site of biochemical interactions among soil components, plants, and microorganisms. In: Pinton R, Varanini Z, Paulo \& Nanipieri P (Eds.). The Rhizophere. Biochemistry and Organic Substances at the Soil-Plant Interface. pp. 1-18. Marcel Dekker, Inc. New York-Basel. 
Podile AR \& Kishore GK. 2007. Plant growth-promoting rhizobacteria. In: Gnanamanickam SS (Ed.). Plant-Associated Bacteria. pp. 195-230. Springer. The Netherlands.

Semangun H. 1991. Penyakit-Penyakit Tanaman Perkebunan Indonesia. Gadjah Mada University Press. Yogyakarta.

Wuryandari Y, Purnawati A, \& Siswanto. 2011. Effect of Formulation with Pseudomonad fluoresen Isolate Pf-122 for Progress of Tobacco Bacterial Wilt Disease. The International Seminar on Natural Resources, Climate Change, and Food Security in Developing Countries. ISBN 978-602-8915-93-9.
Wuryandari Y, Wiyatiningsih S, \& Sulistyono A. 2012. Induksi Pertumbuhan dan Ketahanan Tanaman Cabai terhadap Penyakit Utama Layu Ralstonia solanacearum dan Fusarium oxysporum menggunakan Rhizobacteria. Laporan penelitian Strategis Nasional. Dikti 2012. Jakarta. 